\title{
OZONE FEATURES IN THE CONTEXT OF AD- VANCING COVID-19 PANDEMIC
}

\author{
Galina Yaneva ${ }^{1}$, Dobri Ivanov ${ }^{1}$, Diana Ivanova ${ }^{2}$ \\ 1) Department of Biology, Faculty of Pharmacy, Medical University, Varna, Bul- \\ garia. \\ 2) Department of Biochemistry, Molecular Medicine and Nutrigenomics, Fac- \\ ulty of Pharmacy, Medical University, Varna, Bulgaria.
}

\begin{abstract}
:
Coronavirus disease 2019 represents a serious challenge for modern society worldwide because of the considerable and unfavourable consequences of the pandemic in terms of human health, economics and social life. In the present survey, some essential peculiarities of ozone as an air pollutant and powerful oxidant under the conditions of the COVID-19 pandemic as reflected in the recent literature are described. The understanding of ozone chemistry during COVID-19 lockdown can improve ozone parameterization in models of chemical transport. Ozone peroxides such as ozonides, aldehydes, hydrogen peroxides, and organic peroxide serve as messengers to modulate the human immune system and improve blood rheology.
\end{abstract}

Keywords: COVID-19 pandemic, ozone, air pollution, ozone oxidation,

\section{BACKGROUND}

The COVID-19 pandemic is the largest global health crisis in decades resulting apart from the unprecedented number of deaths and hospitalizations in economic slowdowns, widespread business disruptions, and significant hardships [1]. United efforts of researchers and clinicians lead to gradual improvement of this unpleasant situation.

In the mid-nineteenth century, ozone gas is discovered as a molecule consisting of three atoms of oxygen [2]. Its dynamically unstable structure is due to mesomeric states presence [2]. Ozone leads to dose-dependent oxidative stress because of its ability to produce free radicals deriving from the lipoperoxidation of cell membranes, enzyme inactivation, protein oxidation, DNA destruction, and cell apoptosis [3].

As gas ozone occurs in the Earth's upper atmosphere (stratosphere) and at ground level [4]. Stratospheric ozone is 'good', acting as a barrier for ultraviolet rays. Ozone in the troposphere and at the ground level represents a secondary air pollutant generated through several complex photochemical reactions which involve solar radiation and ozone-precursors.

The objective of the present survey is to systema- tize the recent scientific achievements concerning the role of ozone as an air pollutant and powerful antioxidant in the context of the advancing COVID-19 pandemic.

\section{REVIEW RESULTS}

\section{Peculiarities of ozone as an air pollutant}

Ozone represents the principal main photochemical component of polluted air [5].

Recently, air pollutant concentrations under the conditions of the COVID-19 pandemic are intensively studied. Air pollution represents a factor exacerbating the impact of the COVID-19 virus and potentially serves to its dissemination [6].

During the COVID-19 pandemic, a classification model by reduced-space Gaussian process regression is used to analyze air quality concerning ozone and other pollutants in March and April 2020 in Lima, Peru [7].

In March 2020, the levels of ozone and other three air pollutants were compared to those in 2015-2019 in São Paulo, Paris, Los Angeles, CA and New York, NY controlling for meteorological variables [8]. In March 2020, tropospheric ozone concentrations increased, except in Los Angeles, CA. They are higher in São Paulo, New York, and Paris and, possibly, increase health risks.

Concerning COVID-19, recent differences in social aspects of community transmissions and testing policies, as well as factors that could explain the high discrepancy in regions with a similar healthcare level, remain unknown [9]. Ozone is oppositely related to the number of infected individuals.

Procedures of environmental infection control should be introduced in order to reduce the spread of the COVID-19 virus [10].

During the lockdown, countries like Brazil and India register higher ozone levels $[11,12]$. This is attributed to a nitrogen oxides' reduction [11]. The decreased nitrogen oxides should plummet ozone levels since they are precursors of ozone. The presence of nitrogen oxides and sunlight facilitates the formation of tropospheric ozone.

During a data-driven ecological study performed in 154 cities in China, the basic reproductive number quantifies the COVID-19 transmissibility [13]. This transmissibility is negatively related to ambient ozone. The daily one- 
hour maximal ozone can cover $7.6 \%$ of the variability of COVID-19 transmissibility.

According to air pollution data in 55 Italian province capitals and the number of individuals infected on Apr 7,2020 , it has been concluded that there is a strong association of COVID-19 acceleration and vast diffusion in Northern Italy with air pollution of cities by ozone or fine particulate matter $\leq 10 \mu \mathrm{m}$ [14]. The COVID-19-related accelerated transmission dynamics is mainly due to an 'air pollution-to-human transmission' (airborne viral infectivity) mechanism.

In January-April 2020, the dynamic changes of daily average inhalable gaseous pollutants ozone and nitrogen dioxide as well as of several climate variables in the metropolitan area of Milan, Lombardy region, Italy, are analyzed [4]. Elevated urban air pollution along with climate conditions exerts a significant effect on SARS-CoV2 infection diffusion. Ambient ozone levels positively correlate with the increased COVID-19 infection rates and are attributed to the distribution of airborne bioaerosols. Daily averaged ozone positively correlates with air temperature but inversely with rates of relative humidity and precipitation. Ozone can act as a COVID-19 virus incubator [4].

The associations among ozone, fine particulate matter $2.5 \mu \mathrm{m}$ and several daily meteorological variables, on the one hand, and new confirmed cases of COVID-19 in Queens county, New York, NY, on the other hand, during March and April 2020 are explored by regression modeling [15]. The daily maximal eight-hour ozone concentration, daily mean temperature, mean relative humidity, and percentages of clouds are significantly and positively related with COVID-19 new confirmed cases. The ozone level (daily maximal eight-hour concentration) gradually increases during the observation period and ranges from $0.031 \pm 0.04$ to $0.053 \pm 0.005 \mathrm{ppm}$. During the critical stage of infection initiation or SARS-CoV-2 virus replication, there is evidence of direct influences of some pollutants such as ozone [15].

Temporal air pollution changes in four representative megacities (Wuhan, Beijing, Guangzhou and Shanghai) in Southern, Northern, Eastern, and Central China, are twofold assessed, one week before and one week after COVID19 outbreak onset [16]. The average ozone level increases significantly during the second period (from $65 \pm 14 \mu \mathrm{g} / \mathrm{m} 3$ to $82 \pm 11 \mu \mathrm{g} / \mathrm{m} 3$ ) due to non-meteorological factors.

Ozone levels in Rio de Janeiro increase during the lockdown for COVID-19 in March 2020, which is attributed to the increased ratios of non-methane hydrocarbons and nitrogen oxides as atmospheric chemistry in this city is already under control [17]. They are higher in March 2020 than in the same period in 2019 , probably, because of the reduced levels of nitrogen oxides [11].

The changes of air quality index for a primary air pollutant, fine particulate matter $2.5 \mu \mathrm{m}$, and a secondary air pollutant, ozone, were assessed in December 2019, April 2020 and May 2020 during the COVID-19 pandemic in Turkey [18]. The ozone air quality index increases from 16.8 to 28.8 by the end of April because of the reduction of fine particulate matter concentrations, which enhances sunlight penetration.
The effect on air pollution with amplified ozone of COVID-19 pandemic-related lockdown in four cities in Southern Europe (Rome, Turin, Valencia and Nice) as well as in a city in Southern China (Wuhan) is quantitatively estimated in 2020 [19]. During the lockdown in 2020, the daily average concentrations of ozone increase at urban stations by $14 \%$ in Rome, $27 \%$ in Turin, $2.4 \%$ in Valencia, $24 \%$ in Nice and $36 \%$ in Wuhan when compared to the same period in 2017-2019. The lockdown exerts a higher effect on ozone production by $\sim 10 \%$ than the weekend effect in these European cities but a much higher one (by $38 \%$ ) in Wuhan [19].

During COVID-19 restrictions in Australia, the levels of ozone and particulate matter $<2.5 \mu \mathrm{m}$ are effectively unchanged in the state of Victoria but increase by $20 \%$ and $24 \%$, respectively, in the state of New South Wales, suggesting the stronger reduction of community mobility in Victoria than in New South Wales [20]. New SARS-CoV-2 cases and mortality rate increase in the provinces of Lombardi, Italy, and neighboring regions in case of distance from Lodi below 92 and $140 \mathrm{~km}$, respectively, as these relationships are amplified by ozone pollution [21]. Ozone response during COVID-19 lockdown is due to the resolving of the complex mechanism of ozone, nitrogen oxides and volatile organic compounds, according to the results from air monitoring stations in Delhi, India [22]. The understanding of ozone chemistry can improve ozone parameterization in models of chemical transport.

\section{Peculiarities of ozone as a powerful oxidant}

As a triatomic allotrope form of oxygen, ozone has a higher oxidant potency than oxygen and the third one after fluorine and persulfate [23]. When contacting the organic molecules, it demonstrates a paradoxical activity and induces a powerful antioxidant response [24]. Ozone leads to the creation of hydroperoxides and particularly hydrogen peroxide during its reaction with some target substrates in biological fluids (polyunsaturated fatty acids, glutathione and aldehydes). Besides, it quickly disseminates through immune cells. It biologically regulates signal transduction and, in this way, promotes immune responses, modulates interferon and interleukins through nuclear factor kappa B activation and increases cytokine release [24].

Ozone displays an anti-oxidizing and anti-inflammatory action [25]. Both nuclear factor erythroid 2-related factor and nuclear factor kappa B represent transcription agents modulating the gene expression of the proinflammatory and anti-inflammatory cytokines.

Ozone can reduce lung function and increase hospital admission rates. Ozone exposure can lead to respiratory symptoms or short-term alterations of mortality rates. A limit for ozone exposure of $100 \mu \mathrm{g} / \mathrm{m}^{3}$ at an 8-hour average is considered [26]. According to a new statement assessment, the epidemiologic investigations are in agreement with a relationship of pulmonary function impairment at ozone concentrations as low as $33 \mathrm{ppb}\left(62.2 \mu \mathrm{g} / \mathrm{m}^{3}, 8\right.$ hour average) [27].

Ozone enhances host immunity by increasing cytokine production [28]. After activation, antibody-coated 
neutrophils produce an oxidant possessing the chemical signature of ozone [29].

In COVID-19, the ozone-depleting-like halogen cyclic reactions which enhance the effects of reactive halogen species are responsible for these functions that are activated by hydrogen peroxide and then deactivated by nitrogen oxide signaling molecule [30]. These cycles are repeated many times, and they amplify the pathogen-killing (defense) effects of the reactive halogen species in phagocytosis by 100000 fold and resemble the stratospheric cyclic ozone-depleting reactions.

Ozone-induced interleukin-33 activates internal Th1 and CD8 T-cell reactions and drives the protective immunity against viral infections [13]. In preclinical settings, the interleukin-33 is used as an adjuvant in influenza vaccines for stimulation of the antigen-specific immunoreactions $[31,32]$. Ozone statistically significantly increases interleukin-8 levels in comparison to those for ambient particulate matter $<1 \mu \mathrm{m}$ dissolved in solution without exposure to ozone and the solvent only $(8.2 \pm 0.9 \mathrm{pg} / \mathrm{mL})$ [33]. This happens by a mechanism that is not related to reactive oxygen species in a manner that depends on ozone concentration.

The concept of oxidative preconditioning is shown at proteomic and genomic levels [34] as well as in clinical trials and in in vitro studies [35]. A calibrated oxidant stimulus by oxygen/ozone modulates the system of endogenous antioxidants and helps to control the various pathological conditions [36].

Ozone reacts through free radicals' oxidation, peroxidation or generation and enhancement of cascade of reactions like lipid peroxidation, thus changing the membrane permeability [37]. Ozone reacts immediately with blood components to produce less powerful but still potent redox oxidizing molecules (ozone peroxides) such as ozonides, aldehydes, hydrogen peroxides, and organic peroxide [38]. These molecules serve as messengers to modulate the immune system and improve blood rheology. Ozone is produced by the human body aiming at its protection from infectious agents. This is accomplished by neutrophils and antibodies, which apply ozone's oxidizing capacity for the destruction of bacteria and viruses on cellular walls.

In 43 college students in Shanghai, real-time personal ambient short-term ozone exposure levels, serum angiotensin-converting enzyme, endothelin-1 and methylation of locus-specific DNA of angiotensin-converting enzyme and gene EDN1 encoding endothelin-1 are quantitatively estimated, and potentially important metabolites are explored using an untargeted metabolomics approach [39]. There is a significant association between an increased two hour-average exposure of ozone and higher values of blood pressure, angiotensin-converting enzyme and endothelin1. Methylation of both angiotensin-converting enzyme and gene EDN1 decreases with ozone exposure.

The effect of ozone on healthy human hemoglobin in whole blood (in antioxidant presence) and in purified form (in antioxidant absence) is studied by means of circular dichroism and ultraviolet-VIS absorption spectroscopy, SDS- and Native-PAGE intrinsic fluorescence as well as using dynamic light scattering [40]. The absence of antioxidants increases damage to hemoglobin due to higher exposure to ozone, while their presence avoids this damage.

There are different pharmacological properties of ozone, and its pharmacological effects in various organs and under clinical conditions as possible biochemical and molecular insights for its biological properties are available [5].

Glycolysis acceleration belongs to the main effects of ozone [5].

\section{CONCLUSION}

This concise survey allows us to draw the conclusion that ozone has an undoubted dual role - as an air pollutant under the conditions of advancing COVID-19 pandemic and a beneficial effect as an inexpensive oxidizing agent in the fight against SARS-CoV-2 in our united world. Further interdisciplinary research could provide additional evidence of these roles with regard to the application of various ozonizing appliances widely used in clinical and in-home settings recently.

\section{REFERENCES:}

1. Alsharef A, Banerjee S, Uddin SMJ, Albert A, Jaselskis E. Early impacts of the COVID-19 pandemic on the United States construction industry. Int J Environ Res Public Health. 2021 Feb 6;18(4):1559. [PubMed]

2. Elvis AM, Ekta JS. Ozone therapy: a clinical review. J Nat Sci Biol Med. 2011 Jan;2(1):66-70. [PubMed]

3. Cross CE, Reznick AZ, Packer L, Davis PA, Suzuki YJ, Halliwell B. Oxidative damage to human plasma proteins by ozone. Free Radic Res
Commun. 1992;15(6):347-52. [PubMed]

4. Zoran MA, Savastru RS, Savastru DM, Tautan MN. Assessing the relationship between ground levels of ozone $\left(\mathrm{O}_{3}\right)$ and nitrogen dioxide $\left(\mathrm{NO}_{2}\right)$ with coronavirus (COVID-19) in Milan, Italy. Sci Total Environ. 2020 Oct 20;740:140005. [PubMed]

5. Di Mauro R, Cantarella G, Bernardini R, Di Rosa M, Barbagallo I, Distefano A, et al. The biochemical and pharmacological properties of ozone: the smell of protection in acute and chronic diseases. Int J Mol Sci. 2019 Feb;20(3):634. [PubMed]

6. Isaifan RJ. The dramatic impact of Coronavirus outbreak on air quality: Has it saved as much as it has killed so far? Glob J Environ Sci Manag. 2020;6(3):275-288. [Crossref]

7. Arias Velásquez RM, Mejía Lara JV. Gaussian approach for probability and correlation between the number of COVID-19 cases and the air pollution in Lima. Urban Climate. 2020 Sep;33:100664. [PubMed]

8. Connerton P, Vicente de 
Assunção J, Maura de Miranda R, Dorothée Slovic A, José PérezMartínez P, Ribeiro H. Air quality during COVID-19 in four megacities: Lessons and challenges for public health. Int J Environ Res Public Health. 2020 Jul;17(14):5067. [PubMed]

9. Fronza R, Lusic M, Schmidt M, Lucic B. Spatial-temporal variations in atmospheric factors contribute to SARS-CoV-2 outbreak. Viruses. 2020 May;12(6):588. [PubMed]

10. Ong SWX, Tan YK, Chia PY, Lee TH, Ng OT, Wong MSY, et al. Air, surface environmental, and personal protective equipment contamination by severe acute respiratory syndrome coronavirus 2 (SARS-CoV-2) from a symptomatic patient. JAMA. 2020 Apr;323(16):1610-1612. [PubMed]

11. Dantas G, Siciliano B, França BB, da Silva CM, Arbilla G. The impact of COVID-19 partial lockdown on the air quality of the city of Rio de Janeiro, Brazil. Sci Total Environ. 2020 Aug 10;729:139085. [PubMed]

12. Sharma S, Zhang M, Anshika JG, Gao J, Zhang H, Kota SH. Effect of restricted emissions during COVID19 on air quality in India. Sci Total Environ. 2020 Aug 1;728:138878. [PubMed]

13. Ran J, Zhao S, Han L, Chen D, Yang Z, Yang L, et al. The ambient ozone and COVID-19 transmissibility in China: A data-driven ecological study of 154 cities. J Infect. 2020 Sep;81(3):e9-e11. [PubMed]

14. Coccia M. Factors determining the diffusion of COVID-19 and suggested strategy to prevent future accelerated viral infectivity similar to COVID. Sci Total Environ. 2020 Aug 10;729:138474. [PubMed]

15. Adhikari A, Yin J. Short-term effects of ambient ozone, PM (2.5) and meteorological factors on COVID-19 confirmed cases and deaths in Queens, New York. Int J Environ Res Public Health. 2020 Jun;17(11):4047. [PubMed]

16. Zhao YB, Zhang K, Xu XT, Shen HZ, Zhu X, Zhang YX, et al. Substantial changes in nitrogen dioxide and ozone after excluding meteorological impacts during the COVID-19 outbreak in mainland China. Environ Sci Technol Lett. 2020 May 18;7(6):402-408. [PMCID]
17. Siciliano B, Dantas G, da Silva CM, Arbilla G. Increased ozone levels during the COVID-19 lockdown: Analysis for the city of Rio de Janeiro, Brazil. Sci Total Environ. 2020 Oct 1;737:139765. [PubMed]

18. Aydýn S, Nakiyingi BA, Esmen C, Güneysu S, Ejjada M. Environmental impact of coronavirus (COVID-19) from Turkish perceptive. Environ Dev Sustain. 2020 Aug 13;1-8. [PubMed]

19. Sicard P, De Marco A, Agathokleous E, Feng Z, Xu X, Paoletti E, et al. Amplified ozone pollution in cities during the COVID-19 lockdown. Sci Total Environ. 2020 Sep 15;735:139542. [PubMed]

20. Ryan RG, Silver JD, Schofield R. Air quality and health impact of 2019-20 Black Summer megafires and COVID-19 lockdown in Melbourne and Sydney, Australia. Environ Pollut. 2021 Apr 1;274:116498. [PubMed]

21. Tripepi G, Plebani M, Iervasi G, Gori M, Leonardis D, D’Arrigo G, et al. Distance from the outbreak of infection, ozone pollution and public health consequences of SARS-CoV-2 epidemic: the HOPE method. Eur $J$ Public Health. 2021 Feb 1;31(1):7-12. [PubMed]

22. Rathod A, Sahu SK, Singh S, Beig G. Anomalous behaviour of ozone under COVID-19 and explicit diagnosis of $\mathrm{O}_{3}-\mathrm{NO}_{\mathrm{x}} \mathrm{VOCs}$ mechanism. Heliyon. 2021 Feb;7(2):e06142. [PubMed]

23. Bocci V. Ozone: A new medical drug. 2nd ed. Dordrecht, Springer. 2011, pp. XXI, 315. [Crossref]

24. Jiang HJ, Chen N, Shen ZQ, Yin J, Qiu ZG, Miao J, et al. Inactivation of poliovirus by ozone and the impact of ozone on the viral genome. Biomed Environ Sci. 2019 May;32(5):324-333. [PubMed]

25. Valdenassi L, Franzini M, Ricevuti G, Rinaldi L, Galoforo AC, Tirelli U. Potential mechanisms by which the oxygen-ozone (O2-O3) therapy could contribute to the treatment against the coronavirus COVID19. Eur Rev Med Pharmacol Sci. 2020 Apr;24(8):4059-4061. [PubMed]

26. Air quality guidelines. Global update 2005. Geneva: WHO Europe. 2006. [Internet]

27. Integrated Science Assessment (ISA) for Ozone and Related Photo- chemical Oxidants (Final Report, Apr 2020). US. EPA. Apr 20, 2020. [Internet]

28. Bocci V. Ozonization of blood for the therapy of viral diseases and immunodeficiencies: A hypothesis. Med Hypotheses. 1992 Sep;39(1):304. [PubMed]

29. Babior BM, Takeuchi C, Ruedi J, Gutierrez A, Wentworth P Jr. Investigating antibody-catalyzed ozone generation by human neutrophils. Proc Natl Acad Sci USA. 2003 Mar 18; 100(6):3031-4. [PubMed]

30. Lu QB. Reaction cycles of halogen species in the immune defense: Implications for human health and diseases and the pathology and treatment of COVID-19. Cells. 2020 Jun 13;9(6):1461. [PubMed]

31. Villarreal DO, Weiner DB. IL33 isoforms: their future as vaccine adjuvants? Expert Rev Vaccines. 2015 Apr;14(4):489-92. [PubMed]

32. Mathews JA, Krishnamoorthy N, Kasahara D, Cho Y, Wurmbrand AP, Ribeiro L, et al. IL-33 drives augmented responses to ozone in obese mice. Environ Health Perspect. 2017 Feb;125(2):246-253. [PubMed]

33. Kurai J, Onuma K, Sano H, Okada F, Watanabe M. Ozone augments interleukin- 8 production induced by ambient particulate matter. Genes Environ. 2018 Jul 18;40:14. [PubMed]

34. Pecorelli A, Bocci V, Acquaviva A, Belmonte G, Gardi C, Virgili F, et al. NRF2 activation is involved in ozonated human serum upregulation of HO-1 in endothelial cells. Toxicol Appl Pharmacol. 2013 Feb 15;267(1): 30-40. [PubMed]

35. Delgado-Roche L, Riera-Romo M, Mesta F, Hernandez-Matos Y, Barrios JM, Martinez-Sanchez G, et al. Medical ozone promotes Nrf2 phosphorylation reducing oxidative stress and proinflammatory cytokines in multiple sclerosis patients. Eur $J$ Pharmacol. 2017 Sep 15;811:148154. [PubMed]

36. Galie M, Covi V, Tabaracci G, Malatesta M. The role of Nrf2 in the antioxidant cellular response to medical ozone exposure. Int J Mol Sci. 2019 Aug 17;20(16):4009. [PubMed]

37. Semple JL, Moore GWK. High levels of ambient ozone (O3) may im- 
pact COVID-19 in high altitude mountain environments. Respir Physiol Neurobiol. 2020 Sep;280:103487. [PubMed]

38. Rowen RJ, Robins HR. A plausible "penny" costing effective treatment for corona virus - ozone therapy. J Infect Dis Epidemiol. 2020 Mar;6(2): 113. [Crossref]
39. Xia Y, Niu Y, Cai J, Lin Z, Liu $\mathrm{C}$, Li H, et al. Effects of personal shortterm exposure to ambient ozone on blood pressure and vascular endothelial function: a mechanistic study based on DNA methylation and metabolomics. Environ Sci Technol. 2018 Nov 6;52(21):12774-12782. [PubMed]
40. Mehraban F, Seyedarabi A, Seraj Z, Ahmadian S, Poursasan N, Rayati $S$, et al. Molecular insights into the effect of ozone on human hemoglobin in autohemotherapy: Highlighting the importance of the presence of blood antioxidants during ozonation. Int J Biol Macromol. 2018 Nov;119:1276-1285. [PubMed]

Please cite this article as: Yaneva G, Ivanov D, Ivanova D. Ozone features in the context of advancing COVID-19 pandemic. J of IMAB. 2021 Oct-Dec;27(3):3999-4003. DOI: https://doi.org/10.5272/jimab.2021274.3999

Received: 04/03/2021; Published online: 04/10/2021

Address for correspondence:

Prof. Diana Ivanova, $\mathrm{PhD}, \mathrm{DSc}$

Department of Biochemistry, Molecular Medicine and Nutrigenomics, Faculty of Pharmacy, Medical University of Varna,

84 Tsar Osvoboditel Blvd., 9002 Varna, Bulgaria.

E-mail: divanova@mu-varna.bg 